\title{
VOCABULARY DEVELOPMENT OF KINDERGARTEN STUDENTS OF APPLE TREE PRE-SCHOOL SAMARINDA BY USING FLASHCARDS
}

\author{
Nadia Mustika Rachmita \\ Akademi Bahasa Asing Colorado Samarinda, Indonesia \\ nadiarachmita@gmail.com
}

\begin{abstract}
This present study aimed to investigate 14 kindergarten students of Apple Tree pre-school Samarinda with various ability toward their English vocabularies development by flashcards. A Class Action Research was applied in this study. The data was collected through observation checklist, sequence of cycles and interview transcript. Then, building on the analysis of the collected data, it further discusses the vocabulary development of YL and provides suggestions for TEYL. This study revealed that; (1) most of the students developed their English vocabularies gradually by flashcards. (2) These result indicated that TEYL especially kindergarten students by using flashcards could give significant vocabularies development in learning process. Flashcards is one of the simplest and effective teaching materials for teaching YL vocabulary due to the fact that flashcards are categorized based on themes with full colored pictures which attractive for YL. As this study showed the students were engaged with the topics given since the teachers used flashcards to teach English vocabulary. It was difficult to make engagement with YL in English teaching and learning because YL have different mood, self-motivation, and self-confidence which influenced to the willingness in grasping the lesson. Finally, through this based-picture learning, the students indicated that their progress in vocabulary development although this phenomena was commonly happened in TEFL for YL that lead to teaching method done by English teachers who are required to do more innovation toward their teaching method, to develop sufficient knowledge and to use proper teaching media.
\end{abstract}

Keywords: vocabulary development, young learner, flashcard, preschool

\section{INTRODUCTION}

English language is considered as foreign language in Indonesia and it is one of the crucial skills that need to be achieved to face this global era. There are many educational institutions provide English education for young learners. It is the main reason for most parents to send their children to Bilingual schools or the school which provide English program. Beyond this fact, teaching English for young learners is a fascinating scope to observe and teaching preschool students is different from teaching adult due to the fact that they have different characteristics and motivation as well. Therefore, the researcher rises two research problems; (1) Are the kindergarten students in Apple Tree Pre School Samarinda 
interested in learning English through flashcards? And (2) How far the use of flashcards to improve kindergarten students' of vocabulary mastery at Apple Tree Pre-School Samarinda?

This research aims to find out that golden age is very influential in learning foreign language especially in developing their English vocabulary through Flashcards by observing Apple Tree preschool students in Samarinda.

In the context of teaching and learning process, using media is actually important as a preparation step for the teachers who would like to teach young learners due to the fact that media can enhance teaching and learning. The teacher can bring the media into the classroom through visuals, sounds, smells, and tastes because children brains rely heavily on stimulus from the outside for learning, this is just one of the reasons that teaching with media is brain friendly.

In relation to the teaching and learning process, this media is not only braincompatible learning because it is comfortable for the young learners. For example, most learners are either visual or kinesthetic, thus a brain-friendly environment will lean heavily on teaching methods that include visuals, models, or hands-on activities.If students need more time to learn, more time is given rather than sticking to a fixed timetable, regardless of the quality of the learning.

\section{METHODOLOGY}

The method used in this research is classroom Action Research (CAR). According to Wallace (1998), classroom Action Research (CAR) is a type of classroom research carried out by the teacher in order to solve probelms or to find answer toward context-specific issues. It means that before implementing the Classroom Action Research (CAR), the researcher or the teacher needs to identify any problems real found in the classroom before implementing the CAR.

\section{Research Subjects}

The subjects of this study were 14 students of Kindergarten class in Apple Tree PreSchool. The subjects were selected based on their various reading interest, age, and English capability since they are also from different background. Their age range was from 4 to 5 years old. Some of them have already recognized some basic English vocabularies, most of them haven't known yet. The teacher used full English in the classroom.

Script Journal Volume 1, Issue 2, October 2016 || P-ISSN 2477-1880 || E-ISSN 2502-6623 http://jurnal.fkip-uwgm.ac.id/index.php/Script 


\section{Data Collection Technique}

In this study, the researcher used a few techniques in collecting data from the young learners as the participants in this study. The process of the collecting data is through these following phases:

\section{Observation}

Observation is one way that can be done for collecting data. As the researcher has mentioned in the previous chapter that observation is one thing that must be included in the action research because it is one of the stages of action research cycles. In this classroom action research, the researcher chose participant observation. The researcher worked with the English teacher in conducting the research, the researcher has role as an observer.

\section{Interview}

The researcher did interview as the data collection technique because the researcher believed that it would help her to get additional data to support the data obtained through observation. So, the researcher contacted the teacher as the interviewee in advance and explained them the purpose of the interview to obtain her permission. Next, the researcher scheduled an appointment and agreed on where the interview would be held. The place was neutral, confidential, comfortable, quiet, free of distractions and easily accessible for the interviewee. The interview took about 30 minutes and use open-ended questions that flow naturally in Indonesian language. During the interview, the researcher also recorded the conversation in order to be easier to make transcripts then as the interview result. In the process of analyzing the interview transcripts, the researcher did some steps. Firstly, the researcher read the transcripts by quickly browsing through all transcripts as a whole, and read carefully line by line. Second, the researcher labeled relevant pieces which are relevant words, phrases, sentences, or sections in coding process. Next step, the researcher decided which codes were the most important and created themes by bringing several codes together. Then, she drew a figure to summarize the results.

As the instrument development, the researcher employed checklist and interview guidelines to obtain the data.. In this study, interview guideline was an instrument for the researcher to ensure that none of the important issues to be discussed is left out of the 
conversation. In examining the lived experiences of the participants in this study, the researcher conducted in-depth interview. In-depth interviewing is a qualitative research technique that involves conducting intensive individual interviews with a small number of respondents to explore their perspectives on a particular idea, program, or situation. The researcher also applied open-ended questions with semi-structured format to seek understanding and interpretation and also recorded the responses which are determined as the characteristics of this kind of interview. In order to be organized, the researcher followed the interview processes which are seven stages of conducting in-depth interviews by Kvale (1996), thematizing, designing, interviewing, transcribing, analyzing, verifying, and reporting.

\section{Data Analysis Technique}

To analyze the data, the researcher uses the flow model analysis proposed by Miles \& Huberman (1994). They got definition of analysis as consisting of three concurrent flow activities; data reduction, data display, and conclusion drawing/verification. Data reduction refers to the process of selecting, focusing, simplifying, abstracting, and transforming raw data by writing notes. In this process, the researcher focused on her analysis dealing with a series of the process to summarize the other information and supporting data that she got from several books. Data analysis was focused on the object that would be improved which was the vocabulary development of kindergarten students with different abilities and age. The data was numerical with verbal description according to the students' outcome and analyzed descriptively. Then, the researcher displayed the final data that indicated significant progress or development dealing with vocabulary. Through all these data, the researcher could get more information about the students' progress, so that it can support her in developing the ideas related to vocabulary development theory.

In the data display, the researcher listed down the data into an organized, compressed assembly of information that permitted conclusion drawing and action. Data display was making notes about the data that the researcher wanted to investigate and made explanations through the quotations by drawing specific, simple, and definite piece of data. The last was conclusion and verification activity. In this step, each data that had been analyzed would be checked again to see the proper data and theories for this study. Then, the researcher clarified the result according to experts' opinion. Briefly, she adjusted all the data that had been analyzed to students' vocabulary development of kindergarten class.

Script Journal Volume 1, Issue 2, October 2016 || P-ISSN 2477-1880 || E-ISSN 2502-6623

http://jurnal.fkip-uwgm.ac.id/index.php/Script 


\section{FINDING}

In this section, the researcher presented the discussion of the students' interest in learning English vocabulary by using flashcards and the development of their vocabulary acquisition during the learning center.

The target of this research was accomplished that the students could improve their vocabulary gradually. It was indicated by the tables that all students could enjoy learning English lesson. Second, more or less $80 \%$ of the students could improve their vocabulary, it can be seen most of them were able to use English words in simple sentences; they were able to understand the meaning, and good at pronunciation. The last, $80 \%$ of the students could study English more effective. Flashcards gave significant influence toward English vocabularies learning and also produced the students' learning outcome by showing their progress in motivation, self confidence as well as their learning awareness in the classroom. Although based on the researcher's observation in Apple Tree Pre School Samarinda, most of students get difficulties in mastering English vocabulary beforehand. It can be seen from their preliminary study that most of.table 1 below

\begin{tabular}{|l|l|l|l|l|l|l|l|l|l|l|l|l|l|c|}
\hline \multirow{2}{*}{ No } & \multirow{2}{*}{ Student } & \multicolumn{9}{|c|}{ Number of item } \\
\cline { 2 - 14 } & & $\mathbf{1}$ & $\mathbf{2}$ & $\mathbf{3}$ & $\mathbf{4}$ & $\mathbf{5}$ & $\mathbf{6}$ & $\mathbf{7}$ & $\mathbf{8}$ & $\mathbf{9}$ & $\mathbf{1 0}$ & $\mathbf{1 1}$ & $\mathbf{1 2}$ & Total \\
\hline 1 & Agresia & 1 & 1 & 1 & 0 & 0 & 0 & 0 & 0 & 1 & 0 & 0 & 1 & 50 \\
\hline 2 & Audrey & 0 & 1 & 0 & 0 & 1 & 0 & 0 & 1 & 1 & 0 & 0 & 0 & 40 \\
\hline 3 & Callysta & 1 & 0 & 1 & 0 & 1 & 1 & 0 & 1 & 0 & 0 & 1 & 1 & 70 \\
\hline 4 & Edelweiss & 0 & 0 & 1 & 0 & 1 & 1 & 0 & 1 & 0 & 1 & 0 & 1 & 60 \\
\hline 5 & Giggsy & 0 & 0 & 0 & 1 & 0 & 0 & 1 & 0 & 0 & 1 & 1 & 0 & 40 \\
\hline 6 & James & 0 & 0 & 1 & 0 & 1 & 0 & 0 & 1 & 0 & 0 & 1 & 1 & 50 \\
\hline 7 & Jesslyn & 0 & 1 & 0 & 0 & 1 & 1 & 1 & 1 & 0 & 1 & 0 & 1 & 70 \\
\hline 8 & Kaylee & 1 & 1 & 1 & 1 & 0 & 0 & 1 & 0 & 0 & 0 & 1 & 0 & 60 \\
\hline
\end{tabular}

Script Journal Volume 1, Issue 2, October 2016 || P-ISSN 2477-1880 || E-ISSN 2502-6623 http://jurnal.fkip-uwgm.ac.id/index.php/Script 


\begin{tabular}{|l|l|c|c|c|c|c|c|c|c|c|c|c|c|c|}
\hline \multirow{2}{*}{ No } & \multirow{2}{*}{ Student } & \multicolumn{10}{|c|}{ Number of item } \\
\cline { 4 - 15 } & & $\mathbf{1}$ & $\mathbf{2}$ & $\mathbf{3}$ & $\mathbf{4}$ & $\mathbf{5}$ & $\mathbf{6}$ & $\mathbf{7}$ & $\mathbf{8}$ & $\mathbf{9}$ & $\mathbf{1 0}$ & $\mathbf{1 1}$ & $\mathbf{1 2}$ & Total \\
\hline 9 & Matthew & 0 & 1 & 0 & 1 & 0 & 0 & 0 & 1 & 1 & 1 & 1 & 0 & 60 \\
\hline 10 & Michelle & 1 & 1 & 1 & 1 & 0 & 1 & 1 & 1 & 0 & 0 & 0 & 0 & 70 \\
\hline 11 & Nicholle & 0 & 1 & 1 & 1 & 1 & 0 & 0 & 1 & 0 & 0 & 1 & 0 & 60 \\
\hline 12 & Nicolas & 1 & 1 & 0 & 0 & 0 & 1 & 1 & 0 & 1 & 0 & 1 & 1 & 70 \\
\hline 13 & Fifi & 1 & 0 & 0 & 1 & 1 & 1 & 1 & 0 & 1 & 0 & 0 & 0 & 60 \\
\hline 14 & Kenneth & 0 & 0 & 1 & 1 & 1 & 0 & 1 & 0 & 0 & 0 & 0 & 1 & 50 \\
\hline
\end{tabular}

Table 1 Preliminary study

Their English vocabulary competence is still slow. The indicators of the problems are as follows, the students cannot pronounce the English words well, they cannot understand the meaning of English words, they cannot use the English word and so on. The students' difficulties as stated above could be caused by some factors. In this case, the teacher has a very important role to support the students' English achievement in teaching learning process. The explained the material of the lesson, The time was limited. Teaching learning process became static and the students sometimes felt bored.

It is one of teaching techniques to improve or enhance the students' English vocabulary mastery. Richards (2006) explains some of benefits of picture (flashcard) in teaching language, including; pictures provide authentic cultural information, pictures have positive effect on learner motivation, provide exposure to real language, pictures relate more closely to learners' need and support more creative approach to teaching. From the data above, the teacher noticed there is a slight increase from the preliminary study. This improvement can show the researcher that the students still had difficulty to grasp the vocabulary. 


\begin{tabular}{|c|c|c|c|c|c|c|c|c|c|c|c|c|c|}
\hline \multirow{2}{*}{ No } & \multirow{2}{*}{ Student } & \multicolumn{12}{|c|}{ Number of item } \\
\hline & & 1 & 2 & 3 & 4 & 5 & 6 & 7 & 8 & 9 & 10 & 11 & 12 \\
\hline 1 & Agresia & 1 & 1 & 1 & 0 & 1 & 0 & 1 & 0 & 1 & 0 & 0 & 1 \\
\hline 2 & Audrey & 0 & 1 & 0 & 0 & 1 & 0 & 0 & 1 & 1 & 0 & 1 & 1 \\
\hline 3 & Callysta & 1 & 0 & 1 & 0 & 1 & 1 & 1 & 1 & 0 & 0 & 0 & 1 \\
\hline 4 & Edelweiss & 0 & 0 & 1 & 0 & 1 & 1 & 0 & 1 & 1 & 1 & 1 & 1 \\
\hline 5 & Giggsy & 1 & 1 & 0 & 1 & 0 & 0 & 1 & 0 & 0 & 1 & 1 & 1 \\
\hline 6 & Jeje & 1 & 0 & 1 & 0 & 1 & 0 & 1 & 1 & 1 & 0 & 1 & 0 \\
\hline 7 & Jesslyn & 0 & 1 & 0 & 0 & 1 & 1 & 1 & 1 & 1 & 1 & 1 & 0 \\
\hline 8 & Kaylee & 1 & 1 & 1 & 1 & 1 & 0 & 1 & 0 & 0 & 0 & 1 & 0 \\
\hline 9 & Matthew & 0 & 1 & 1 & 1 & 0 & 1 & 0 & 1 & 1 & 1 & 0 & 1 \\
\hline 10 & Michelle & 1 & 1 & 1 & 1 & 0 & 1 & 1 & 1 & 0 & 0 & 0 & 1 \\
\hline 11 & Nicholle & 0 & 1 & 1 & 1 & 1 & 0 & 0 & 1 & 0 & 0 & 1 & 0 \\
\hline 12 & Nicolas & 1 & 1 & 1 & 0 & 0 & 1 & 1 & 0 & 1 & 0 & 0 & 1 \\
\hline 13 & Fifi & 1 & 1 & 1 & 1 & 1 & 1 & 1 & 0 & 1 & 0 & 1 & 0 \\
\hline 14 & Kenneth & 0 & 0 & 1 & 1 & 1 & 0 & 1 & 0 & 1 & 1 & 1 & 1 \\
\hline
\end{tabular}

\section{Table 2 Post test of cycle 2}

From the table above, we can see that several students have improved the vocabulary from cycle one to cycle two. For instance, Agresia improved 3 words, Edelweiss got 3 words, Jesslyn got 3 words, Fifi got 5 words and rest of student got 1 to 2 words. After the researcher found this fact, the researcher and collaborator have change several step in planning, acting and observing. The students were more active in doing activities and they had high motivation in joining English lesson. All students could Script Journal Volume 1, Issue 2, October 2016 || P-ISSN 2477-1880 || E-ISSN 2502-6623 http://jurnal.fkip-uwgm.ac.id/index.php/Script 
join in the corner's activities. In the second meeting, there were some students couldn't wait in turn in doing the activities in the corner. The students had high motivation in English lesson, as the result they always join in all activities in the class or corner. They were braver to answer the teacher's questions. The classroom situation was more alive, because there was a life communication between the teacher and the students interactively. It happened during learning process when the teacher asked questions, the students answered the question enthusiastically.

Implementing the action in the second cycle has succeeded in enhancing the students' vocabulary mastery of what they had learned before which was held in the second meeting. After comparing the result of post -test in which the result was fair and the result of post-test in the second cycle was increased

\begin{tabular}{|c|c|c|c|c|c|c|c|c|c|c|c|c|c|}
\hline \multirow{2}{*}{ No } & \multirow{2}{*}{ Student } & \multicolumn{12}{|c|}{ Number of item } \\
\hline & & 1 & 2 & 3 & 4 & 5 & 6 & 7 & 8 & 9 & 10 & 11 & 12 \\
\hline 1 & Agresia & 1 & 1 & 1 & 1 & 1 & 1 & 1 & 0 & 1 & 1 & 1 & 0 \\
\hline 2 & Audrey & 0 & 1 & 0 & 1 & 1 & 0 & 0 & 1 & 1 & 1 & 1 & 0 \\
\hline 3 & Callysta & 1 & 0 & 0 & 1 & 1 & 1 & 1 & 1 & 1 & 0 & 1 & 1 \\
\hline 4 & Edelweiss & 1 & 1 & 1 & 0 & 1 & 1 & 0 & 1 & 1 & 1 & 0 & 1 \\
\hline 5 & Giggsy & 1 & 1 & 1 & 1 & 1 & 0 & 1 & 0 & 1 & 1 & 0 & 1 \\
\hline 6 & James & 1 & 1 & 1 & 1 & 1 & 0 & 1 & 1 & 1 & 0 & 1 & 1 \\
\hline 7 & Jesslyn & 0 & 1 & 0 & 1 & 1 & 1 & 1 & 1 & 1 & 1 & 0 & 0 \\
\hline 8 & Kaylee & 1 & 1 & 1 & 1 & 1 & 0 & 1 & 0 & 1 & 0 & 1 & 1 \\
\hline 9 & Matthew & 0 & 1 & 1 & 1 & 1 & 1 & 0 & 1 & 1 & 1 & 1 & 0 \\
\hline 10 & Michelle & 1 & 1 & 1 & 1 & 0 & 1 & 1 & 1 & 1 & 0 & 1 & 1 \\
\hline 11 & Nicholle & 0 & 1 & 1 & 1 & 1 & 1 & 0 & 1 & 0 & 1 & 1 & 1 \\
\hline
\end{tabular}

Script Journal Volume 1, Issue 2, October 2016 || P-ISSN 2477-1880 || E-ISSN 2502-6623 http://jurnal.fkip-uwgm.ac.id/index.php/Script 


\begin{tabular}{|l|l|c|c|c|c|c|c|c|c|c|c|c|c|}
\hline \multirow{2}{*}{ No } & \multirow{2}{*}{ Student } & \multicolumn{10}{|c|}{ Number of item } \\
\cline { 3 - 15 } & & $\mathbf{1}$ & $\mathbf{2}$ & $\mathbf{3}$ & $\mathbf{4}$ & $\mathbf{5}$ & $\mathbf{6}$ & $\mathbf{7}$ & $\mathbf{8}$ & $\mathbf{9}$ & $\mathbf{1 0}$ & $\mathbf{1 1}$ & $\mathbf{1 2}$ \\
\hline 12 & Nicolas & 1 & 1 & 1 & 0 & 0 & 1 & 1 & 0 & 1 & 1 & 0 & 0 \\
\hline 13 & Fifi & 1 & 0 & 1 & 1 & 1 & 1 & 1 & 1 & 1 & 1 & 1 & 0 \\
\hline 14 & Kenneth & 1 & 0 & 1 & 1 & 1 & 0 & 1 & 0 & 1 & 1 & 0 & 1 \\
\hline
\end{tabular}

Table 3 students improve the vocabulary from cycle two to cycle three

From the table above, we can see that most of students have improved the vocabulary from cycle two to cycle three. For instance, Agresia improved 3 words, James got 3 words, Nicholle got 3 words and rest of student got 1 to 2 words. In addition, from the preliminary study to cycle three as statically data most of the students have improve in vocabulary at least they got one to two new words in each theme. In cycle three was significantly increased and it was shown by the students who were usually not active in the previous cycle begin to be more active and responsive in this cycle. They became active in listening the teacher's explanation, answering teacher's question, repeating the words, pronouncing the difficulties words, so that they could have a fluency in understanding meaning and pronouncing the words. When the students got difficulties, they directly asked the teacher to solve their problems. So they got a solution at once, and they could overcome their mistake soon.

The obvious evidence could be seen from their achievement which was reflected by their score after each action test. The result of observation showed that the students' motivation got improvement. Many of them were able to do the task well. From the reflection, it could be concluded that the third cycle had given a better result in improving the students' motivation in learning English especially English vocabulary development although some low students had to give attention more, so that they would get optimal result in their learning English.

\section{DISCUSSION}

In this part, the researcher provided the discussion of flashcard used to improve the kindergarten students' vocabulary. The research findings show some important points as follows: (1) The improvement of students' vocabulary was increased, (2) the students Script Journal Volume 1, Issue 2, October 2016 || P-ISSN 2477-1880 || E-ISSN 2502-6623 http://jurnal.fkip-uwgm.ac.id/index.php/Script 
were more active in doing activities and they had high motivation in joining English lesson, (3) the classroom situation was more alive and enjoyable, the students were not too crowded. The following were the detail information about the research finding; The improvement of students' vocabulary was increased.

This statement is supported by the following tables which show the pre-test and post test result. The pre-test was taken at the first meeting which has all the students took the oral test. On the other hand, the post test was taken at the end of the class. Having carried out the research in which the teacher used flashcard in teaching English to kindergarten students, their English achievement in English vocabulary development are increased. The following table describes the students' score result in each test which was taken from the end of each cycle.

Based on the finding, the researcher saw that the test result from the first cycle until third cycle got a better progress. It means that the students' vocabulary mastery is improved significantly. First, the students were more active in doing activities and they had high motivation in joining English lesson, and during the learning process of English acquisition through vocabulary development, picture on flashcards can make the students more active in the class. In the corner the students could answer the teacher's question actively; they could do their task well. Second, they learned and worked together with their friends, without disturbing each other. They also had closed relationship among them because in doing activities in the corner they had to work together and change their group. They were braver to answer the teacher's questions. Piaget in Chandler (2009) said that "The children should be active, brave and have high motivation in learning, therefore they will get successful in the future, and the teachers are able to guide them by giving appropriate media, but the most important is the children are able to understand knowledge by finding itself". Through the statement, it could be concluded that we are as teacher should be facilitators for children in order to students proactive, highly motivated, and confident in learning second language, and also teachers must be well prepared for conducting teaching and learning process by using appropriate media, so that children will be able to understand the knowledge transferred by teachers. Additionally, having high motivation and activeness in early education would influence their better future.

Script Journal Volume 1, Issue 2, October 2016 || P-ISSN 2477-1880 || E-ISSN 2502-6623 http://jurnal.fkip-uwgm.ac.id/index.php/Script 
Third, the classroom situation was more alive and enjoyable; the students were not too crowded. The classroom situation was more alive because there was a life communication between the teacher and the students interactively. When the teacher asked questions, the students answered the question enthusiastically. Most of students seemed active and they answered the teacher's question with less mistake. Also, the classroom situation was enjoyable, but the crying student in the class was decreased. To deliver the lesson, the teacher looked more friendly with the students although The classroom was little crowded because most of students tried to answer teacher's question, and if they were able to answer the teacher's question, the class gave applause together.

The researcher concluded that teaching technique by using flashcards really gave big contribution in improving and enhancing the students' English vocabulary, for kindergarten students at Apple Tree Pre-school.

\section{CONCLUSION}

This section would present two important components of this research. First is conclusion that includes summary of overall findings and the second was suggestions for the readers, particularly those who were teachers and the future researchers who would like to conduct the similar scope of study.

The research findings show some important points as follows: (1) The improvement of students' vocabulary was increased, (2) the students were more active in doing activities and they had high motivation in joining English lesson, (3) the classroom situation was more alive and enjoyable, the students were not too crowded. The result of the mean of scores that they got from the third cycle was as follows; the mean of the post test in the first cycle was fair, the mean of the post test in the second cycle was good and the mean of post test in the third cycle was much better than the previous one. This increasing was better than the second cycle. The mean of post test in the third cycle was better than pre-test, post test in the first and second cycle.

The result of observation showed that the students' motivation got improvement. Some students who were not active in the lesson decreased. Their confidence in answering the teacher's questions increased. Many of them were able to do the task well. They also did corner's activities well and they did it on time. The students could obey the rules in doing activities in the corners. Furthermore, the result of interview is firstly when applied

Script Journal Volume 1, Issue 2, October 2016 || P-ISSN 2477-1880 || E-ISSN 2502-6623 http://jurnal.fkip-uwgm.ac.id/index.php/Script 
the method, the significant problem faced mostly is lack of self confidence and motivation in following vocabulary discussion. The teacher also needed more review to achieve learning outcomes and objectives. From the phenomenon the teacher will develop the method which proper with her students' condition and abilities for the next phase but finally, using teaching method by fun media that already applied frequently could increase students' progress specifically on English vocabulary and their achievement in acquiring English language was gradually developed as the teacher's expectation.

\section{BIBLIOGRAPHY}

Chandler, M. J. (2009). Piaget on piaget. British Journal of Psychology (London, England: 1953), 100, 225-228. http://doi.org/10.1348/000712609X414169

Kvale, S. (1996). InterViews: An introduction to qualitative research interviewing. Sage Publications, 129-140. http://doi.org/10.1016/S0149-7189(97)89858-8

Miles, M. B., \& Huberman, A. M. (1994). Qualitative Data Analysis: A Sourcebook of New Methods. California: Sage Publication, Inc.

Richards, J. (2006). Communicative language teaching today. New York: Cambridge University Press.

Wallace, J. M. (1998). Action Research for Language Teachers. Cambridge: Cambridge University Press.

Script Journal Volume 1, Issue 2, October 2016 || P-ISSN 2477-1880 || E-ISSN 2502-6623 http://jurnal.fkip-uwgm.ac.id/index.php/Script 